Brazilian Journal of Microbiology (2011) 42: 261-265

ISSN 1517-8382

\title{
CAMPYLOBACTER INSULAENIGRAE: FIRST ISOLATION REPORT FROM SOUTH AMERICAN SEA LION (OTARIA FLAVESCENS, (SHAW, 1800)
}

\author{
Mario González¹, Maria Paz Villanueva ${ }^{1}$, Lies Debruyne² ${ }^{\text {, Peter Vandamme }}$, Heriberto Fernández ${ }^{1 *}$
}

${ }^{1}$ Institute of Clinical Microbiology, Universidad Austral de Chile, Valdivia, Chile; ${ }^{2}$ Department of Microbiology, University Ghent, Ghent. Belgium.

Submitted: September 29, 2009; Returned to authors for corrections: October 22, 2009; Approved: August 23, 2010.

\begin{abstract}
Campylobacter insulaenigrae have been isolated from different pinnipeds but not from South American sea lion (Otaria flavescens).The aim of this work is to report the first isolation of $C$. insulaenigrae from South American sea lion (Otaria flavescens).The isolate, identified by its phenotypic and molecular characteristics, allow recognizing $O$. flavescens as a new host for $C$. insulaenigrae.
\end{abstract}

Key words: Campylobacter insulaenigrae, Otaria flavescens, South American sea lion, reservoir

The genus Campylobacter, comprises small (0.2-0.9 $\mu \mathrm{m}$ wide and $0.2-5.0 \mu \mathrm{m}$ long), motile, spirally curved Gramnegative bacteria. Since its creation in 1963 by Sebald \& Véron, the taxonomic complexity of the genus Campylobacter has increased by the addition of a variety of Gram-negative, microaerobic to anaerobic, asaccharolytic, and oxidasepositive bacteria. Currently the genus Campylobacter comprises 17 validly named species, six sub-species and two biovars (3).

Campylobacter species are worldwide distributed, being found in a wide range of animals and most of them are principally known as zoonotic pathogens. $C$. jejuni and $C$. coli are recognized as major causes of acute gastroenteritis in industrialized countries as well as in developing countries (6).

In the last years, the identification of other atypical and emerging Campylobacter species has been reported. One of them, C. insulaenigrae, was isolated in 2004 from marine mammals: harbor seals (Phoca vitulina), and a harbor porpoise (Phocoena phocoena) (7). Later, it has been isolated from northern elephant seals (Phocoena phocoena) (Stoddard et al. 2007) and most recently, the first human case of gastroenteritis and septicemia due to $C$. insulaenigrae, was reported (1).

Otaria flavescens (Shaw, 1800), commonly known as the South American sea lion, is a marine mammal found along the coasts of South America and the Falkland Islands. On the Pacific side, breeding colonies are found south of Zorritos $\left(03^{\circ} 40^{\prime} \mathrm{S}\right)$, down to Tierra del Fuego and, on the Atlantic side, in Isla de Los Estados (54\%45'S) in Argentina, and up to Recife dos Tôrres $\left(29^{\circ} 21^{\prime} \mathrm{S}\right.$ ) in Brazil (Rice 1998). The type of sea habitat of $O$. flavescens seems to be associated to the distribution and abundance of food. In general the species tends to feed in shallow waters $(<50 \mathrm{~m}$ deep) in coastal areas, and around the continental slope, where it finds the greatest concentrations of pelagic fish 
and/or marine invertebrates (Riedman 1990).

There are also records of the species entering river mouths (basin of the Uruguay River, basin of the Santa Lucía river, Arroyo Pando and Arroyo Solís in Uruguay) and Atlantic coastal lagunes (13).

The sporadic presence of $O$. flavescens individuals in the Valdivia River is a phenomenon observed through decades and scientifically documented since 1976 (11). In the last five years a colony of about 20 to 30 animals was established in a coastal area of the urban course of the Valdivia River (39 $47^{\prime}$ Southern latitude, $73^{\circ} 15^{\prime}$ Western latitude), being the river their feeding ground and the river sandy beach, the lawn and the pavement of the street existing immediately close to the river their resting grounds.

This prompted us to look for the presence of zoonotic enteropathogenic bacteria in fresh sea lions feces deposited on the pavement. In the course of this investigation, a Campylobacter-like organism was recovered from one of the samples.

Five fecal samples were taken and transported to the laboratory in liquid Cary-Blair medium where the sample was homogenized. For the isolation of Campylobacter species the passive membrane filter method was used (6). Briefly, a $0.45 \mu \mathrm{m}$ membrane filter (Millipore) was placed on two sheep blood agar plate without antimicrobials and $0.2 \mathrm{~mL}$ of the fecal suspension of each sample were placed onto the membrane filters. After $30 \mathrm{~min}$, another $0.2 \mathrm{~mL}$ were added onto the membranes and the filters were removed from the plates $30 \mathrm{~min}$ later. The plates were incubated at $37^{\circ} \mathrm{C}$ and $42^{\circ}$ for up to five days in a $\mathrm{H}_{2}$-enriched microaerobic atmosphere achieved by jar evacuation and filling with a prepared gas mixture containing $\mathrm{N}_{2} / \mathrm{CO}_{2} / \mathrm{O}_{2}$ (84:10:6) adding separately $5 \% \mathrm{H}_{2}$.

After $72 \mathrm{~h}$ of incubation, on the plates incubated at both temperatures, small, round and pleomorphic translucent colonies measuring 0.6 to $1 \mathrm{~mm}$ in diameter were obsered. Gram staining showed curved Gram-negative rods which were 0.2-0.3 $\mu \mathrm{m}$ wide and 3-5 $\mu \mathrm{m}$ long. When observed in wet preparations under phase contrast microscopy, organisms were motile with the characteristic darting movement of Campylobacter sp. The isolate, codified as strain OF1 was oxidase and catalase positive but it was unable to hydrolyze sodium hippurate and indoxyl acetate, being initially presumptively identified as non-jejuni noncoli Campylobacter species. Other phenotypical tests were performed. However, as shown in Table 1, due to variations observed in the results, it was not possible to identify strain OF1 to species level using their phenotypic profile.

Table 1. Phenotypic characteristics of $C$. insulaenigrae strain OF1 compared with $C$. insulaenigrae reported by Foster et al. (7), Stoddard et al. (12) and Chua et al. (1).

\begin{tabular}{|c|c|c|c|c|c|}
\hline \multicolumn{2}{|l|}{ Test } & Foster et al. 2004 & Stoddatd et al. 2007 & Chua et al. 2007 & OF1 (Valdivia) \\
\hline \multicolumn{2}{|l|}{ Catalase } & + & + & + & + \\
\hline \multicolumn{2}{|l|}{ Oxidase } & + & + & + & + \\
\hline \multicolumn{2}{|c|}{ Nitrate reduction } & + & + & + & + \\
\hline \multicolumn{2}{|c|}{$\mathrm{H} 2 \mathrm{~S}$ in TSI } & - & - & - & - \\
\hline \multirow[t]{2}{*}{ Hydrolysis: } & Indoxyl acetate & - & NT & - & - \\
\hline & Hippurate & - & - & - & - \\
\hline \multirow[t]{3}{*}{ Growth at: } & $25^{\circ} \mathrm{C}$ & - & - & - & - \\
\hline & $27^{\circ} \mathrm{C}$ & + & + & + & + \\
\hline & $42^{\circ} \mathrm{C}$ & - & $+/-$ & + & + \\
\hline \multirow[t]{2}{*}{ Growth in: } & $1 \%$ Glycine & + & $+/-$ & - & + \\
\hline & $2 \% \mathrm{NaCl}$ & - & $-(3.5 \%)$ & - & $-(2 \& 3.5 \%)$ \\
\hline \multicolumn{2}{|c|}{ Microaerobic growth } & + & + & + & + \\
\hline \multicolumn{2}{|c|}{ Anaerobic growth } & - & NT & - & - \\
\hline \multicolumn{2}{|c|}{ Cephalothin } & NT & $\mathrm{R} / \mathrm{S}$ & NT & $\mathrm{R}$ \\
\hline \multicolumn{2}{|c|}{ Nalidixic Acid } & NT & $\mathrm{R}$ & NT & $\mathrm{R}$ \\
\hline \multicolumn{2}{|c|}{ L-ALA test } & NT & NT & NT & - \\
\hline \multirow[t]{2}{*}{ Growth in: } & MM & NT & NT & NT & + \\
\hline & Mc Conkey & NT & NT & NT & - \\
\hline
\end{tabular}


Strain OF1 was subsequently analyzed by whole-cell protein electrophoresis and AFLP. For whole-cell protein sodium dodecyl sulphate polyacrylamide gel electrophoresis (SDS-PAGE), the isolate was grown on Mueller-Hinton agar supplemented with $5 \%$ sterile horse blood and incubated at $37{ }^{\circ} \mathrm{C}$ for $48 \mathrm{~h}$ in micro-aerobic conditions (approx. $4 \% \quad \mathrm{O}_{2}, \quad 6.5 \% \quad \mathrm{CO}_{2}, \quad 6.5 \% \quad \mathrm{H}_{2}, \quad 83 \% \quad \mathrm{~N}_{2}$ ). The preparation of whole-cell proteins and SDS-PAGE were performed as described by Pot et al. (8). Normalization of densitometric traces was performed using the GelCompar version 4.2 software (Applied Maths, Belgium). Numerical analysis was performed using the Pearson product moment correlation coefficient and UPGMA with BioNumerics 4.61 software. Numerical comparison of the protein profile of strain OF1 clustered it together with protein profiles of $C$. insulaenigrae reference strains. (Fig. 1) indicating that isolate OF1 represented the same species.

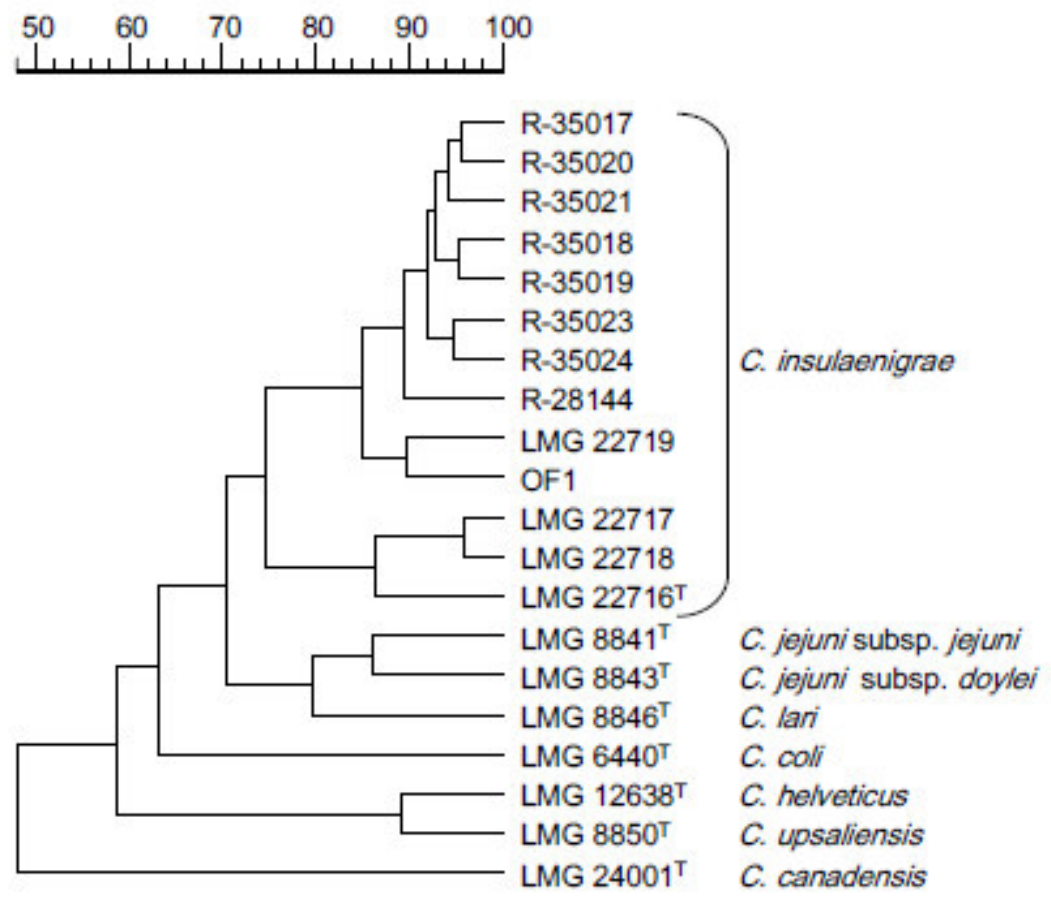

Figure 1. Dendrogram based on the numerical analysis of whole-cell protein profiles of strain OF1, of $C$. insulaenigrae type and reference strains, and of the type strains of related Campylobacter species. C. insulaenigrae strains designated by an LMG strain number are those of the original study by Foster et al. (7); C. insulaenigrae strains designated by R-numbers are Northern elephant seal isolates reported by Stoddard et al. (12).

AFLP-analysis was performed as described by Duim et al. (4). In brief, $1 \mu \mathrm{g}$ of genomic DNA was digested with the HindIII-HhaI restriction enzyme combination. After digestion, site-specific adaptors were ligated to the restriction fragments, and primers complementary to the adaptor and restriction site sequence were used in subsequent preselective and selective PCR amplification reactions. The amplified and fluorescently labelled fragments were loaded on a denaturing polyacrylamide gel on an ABI Prism 377 automated sequencer. GeneScan version 3.1 (Applied Biosystems) was used for data collection, and the generated profiles were imported, using the CrvConv filter, in BioNumerics version 4.61 (Applied Maths, Belgium) for normalization and further analysis. Similarity between normalized profiles was 
determined by the Pearson product moment correlation coefficient and a UPGMA dendrogram was constructed. Again, numerical analysis of the profile of strain OF1 demonstrated that it was indistinguishable from that of $C$. insulaenigrae reference strains.

C. insulaenigrae is phylogenetically closely related to $C$. jejuni, C. coli and C. lari (7). However, due to the variations in the phenotypical tests results reported by Foster et al. (7), Stoddard et al. (12) and Chua et al. (1), and also observed in our isolate, it is difficult to identify $C$. insulaenigrae at the species level by its phenotypic profile. Having in mind that phenotypic methods did not allow the identification of $C$. insulaenigrae, or could lead to misidentification, it is necessary to use molecular methods for the identification of Campylobacter like organisms isolated from marine mammals.

Following CLSI recommendations (2) and our previous experience (5), the antibiotic susceptibility of strain OF1 was determined using the E-test ( $\mathrm{AB}$ Biodisk) method, seeding the strain on Mueller-Hinton agar (Oxoid) supplemented with 5\% horse blood and incubated at $37^{\circ} \mathrm{C}$ for $48 \mathrm{~h}$, under the microaerobic conditions described above.

C. insulaenigrae strain OF1 was susceptible to erythromycin (MIC $0.75 \mathrm{mg} / \mathrm{liter}$ ), tetracycline (MIC 0.064 $\mathrm{mg} /$ liter), chloramphenicol (1.0 MIC mg/liter), ampicillin (0.25 MIC mg/liter) and gentamicin (2.0 MIC mg/liter). These results are in agreement with those published by Chua et al. (1). This strain was also susceptible to clarithromycin (1.0 MIC mg/liter). However, strain OF1 was resistant to the three fluoroquinlones tested (ciprofloxacin, levofloxacin and trovafloxacin [MICs 6.0, 6.0 and $\geq 32 \mathrm{mg} /$ liter, respectively]) as well as to metronidazole (6.0 MIC mg/liter). Our results for levofloxacin, metronidazole, trovafloxacin and clarithromycin could be the first documented information about the susceptibility of $C$. insulaenigrae to these antimicrobial drugs. We consider that it is ecessary to know the behavior of C. insulaenigrae to different antimicrobials, especially if it was found causing enteritis and septicemia in a patient with end-stage hepatic and renal disease, thus being considered as an opportunistic emerging microorganism (1).
Despite the association of $C$. insulaenigrae to septicemia and diarrhea in an immunocompromised patient, its pathogenic potential remains unknown. The strains described by Foster et al. (7) from harbor seals and a harbor porpoise and by Stoddard et al. (12) from northern elephant seals, seemed unrelated to any infectious pathological condition in these animals. Studies are needed to establish if $C$. insulaenigrae is really a commensal or could be a pathogen for marine mammals.

Another aspect to be established is their ecological distribution. Until now, this bacterium has been isolated in Europe (7), North America (12) and South America (strain OF1). Currently, studies are conducted in our laboratory in order to determine the virulence factors of strain OF1 as well as the presence of $C$. insulaenigrae, not only in $O$. flavescens individuals, but also in aquatic birds andtheir water environment.

To the best of our knowledge, this is the first report of the species $C$. insulaenigrae from South America and the first report of $O$. flavescens as a host for this bacterium, expanding their reservoir spectrum.

\section{ACKNOWLEDGMENTS}

This work was supported by the DID-UACh Grants $\mathrm{N}^{\circ}$ S-2007-37 and SE-1-2009.

\section{REFERENCES}

1. Chua, K.; Gürtler, V.; Montgomery J.; Fraenkel, M.; Mayall, B. C.; Grayson. M.L. (2007). Campylobacter insulaenigrae causing septicaemia and enteritis. J. Med. Microbiol. 56, 1565-1567.

2. Clinical and Laboratory Standards Institute. (2006). Methods for Antimicrobial Dilution and Disk Susceptibility Testing of Infrequently Isolated or Fastidious Bacteria; Proposed Guideline. M45-P, 25, 16.

3. Debruyne, L.; Gevers, D.; Vandamme, P. (2008). Taxonomy of the Family Campylobacteraceae, p. 3-26. In Nachamkin I.; Szymansky, C.M.; Blaser, M.J. (ed.), Campylobacter Third Edition. ASM Press, Washington, DC.

Duim, B.; Wassenaar,T. M.; Rigter, A.; Wagenaar, J. A.. (1999). High-resolution genotyping of Campylobacter strains isolated from poultry and humans with AFLP fingerprinting. Appl. Environ. Microbiol. 65, 2369-2375. 
4. Fernández, H.; Mansilla, M.; González, V. (2000). Antimicrobial susceptibility of Campylobacter jejuni subsp. jejuni assessed by Etest and double dilution agar method in Southern Chile. Mem. Instit. Oswaldo Cruz 95, 247-249.

5. Fernández, H.; Vera, F.; Villanueva, M.P.; García, A. (2008). Occurrence of Campylobacter species in healthy well-nourished and malnourished children. Braz. J. Microbiol. 39, 56-58.

6. Foster, G.; Holmes B.; Steigerwalt, A.G.; Lawson, P.A.; Thorne, P.; Byrer, D.E.; Ross, H.M.; Xerry, J.; Thompson, P.M.; Collins, M.D. (2004). Campylobacter insulaenigrae sp. nov., isolated from marine mammals. Int. J. Syst. Evol. Microbiol. 54, 2369-2373.

7. Pot, B.; Vandamme, P.; Kersters, K. (1994). Analysis of electrophoretic whole-organism protein fingerprints, p. 493-521. In Goodfellow, M.; O’Donnell, A.G. (ed.) Modern microbiological methods. Chemical methods in Prokaryotic systematics. John Wiley and Sons, Chichester, England.

8. Rice D. W. (1998). Marine Mammals of the World: systematics and distribution. Special Publication. The Society for Marine Mammalogy 4,1-231.

9. Riedman, M. (1990). The Pinnipeds: seals, sea lions and walruses, p. 1-439. University of California Press. Berkeley / Los Angeles.

10. Schlatter, R.P. (1976). Ingress of the common sea lion, Otaria flavescens shaw, in the Valdivia River and affluents [Chile]. Medio Ambiente (Chile) 2, 86-90.

11. Stoddard, R. A.; Miller, W. G.; Foley, J. E.; Lawrence, J.; Gulland, F. M. D. P.; Conrad, A.; Byrne, B. A. (2007). Campylobacter insulaenigrae Isolates from Northern Elephant Seals (Mirounga angustirostris) in California. Appl. Environ. Microbiol. 73, 1729-1735.

12. Vaz-Ferreira, R. (1982). Otaria flavescens (Shaw), South American Sea Lion. FAO Fisheries Series 4, 477-495. 